\title{
Г.Н. Старикова
}

\section{ПОСОЛЬСКИЕ ОТЧЕТЫ ХVІІ В.: ЖАНРОВОЕ РАЗНООБРАЗИЕ, ЛИНГВИСТИЧЕСКАЯ СОДЕРЖАТЕЛЬНОСТЬ}

\begin{abstract}
Статья посвящена описанию разновидностей документальных текстов конца старорусского периода, содержащих отчеты русских посольств к иностранным дворам: статейным спискам, расспросным речам, отпискам, сказкам, росписям пути. В ней отмечается жанрово-содержательная специфика документов, проблематика филологических исследований на указанном материале. Выявленный характер лингвистической содержательности источников позволяет наметить новые аспекты их изучения в рамках языковедения.

Ключевые слова: лингвистическое источниковедение, посольские отчеты, приказной язык, лингвистическая содержательность, история русского языка.
\end{abstract}

XVII в. занимает особое место в истории России как эпоха великой смуты, церковного раскола, народных восстаний и стрелецких бунтов, одновременно - период географических открытий, присоединения новых земель, установления и развития дипломатических контактов с сопредельными и территориально отдаленными странами. Он же явился временем серьезных преобразований в языковой системе - в частности, данным столетием завершается старорусский и начинается период формирования национального русского языка. Последний процесс во многом обусловлен развитием приказного языка, вызванного, в свою очередь, активизацией деловой жизни государства. В это же время интенсивно развивается литература, расширение жанрового репертуара и общее «обмирщение» которой во многом явились откликом на «прилив» в литературу жанров делопроизводственной письменности [1. С. 320, 346]. В связи со сказанным особый исследовательский интерес вызывает такой тип текстов, как посольские отчеты о поездке в другие страны, характеризующиеся особыми чертами как с позиций жанровосодержательной стороны, так и собственно языковой. Они представлены различными документами (статейные списки, сказки, расспросные речи, отписки, росписи), получившими в научной литературе дополнительные определения: повести послов [1. С. 319], статейные летописи [2. С. 157], путешествия-отчеты [3. С. 82] и др. Чаще всего они обозначаются как статейные списки.

Статейными назывались разного рода жанры делового письма России периода позднего средневековья (XV - начало XVIII в.) - грамоты, росписи, списки, содержащие так называемые статьи - распоряжения, установления регламентирующего характера, входящие как часть в сводный документ (судебный, дипломатический, хозяйственный), а также разделы подобного документа или же сами документы указного типа [4. Т. 28. С. 32]. В современ- 
ной историографии за термином статейный список закрепилось прежде всего значение «отчет посольств к иностранным дворам с поденным освещением событий дипломатической миссии» [4. Т. 28. С. 22]. Дополнением к ним, а иногда и их заменой служили расспросные речи, сказки участников миссии, отписки воевод или других должностных лиц, которым по возвращении домой посланники докладывали о виденном и слышанном в чужих землях. Зачастую они различаются лишь формулярными частями, совпадая в основной, содержательной, части.

Содержание статейного списка во многом было задано наказом посольству. Его следовало сохранять в строгой секретности: «А сей государев наказ держать у себя тайно, чтоб про него нихто у него ни ис каких людей ни один человек не ведал отнюдь никоторыми дель, и в Китаях бы и нигде в проезде про то, о чем он послан, никому не отозвалося. А ему самому сей государев наказ выучить наизусть, чтоб ево помнить весь для того, чтоб ему про все статьи, о которых писано в сем государеве наказе, зделати и проведати подлинно достаточно» - из наказной памяти Ф.И. Байкову [5. С. 164-165]. Как правило, в публикации отчетов послов он включается далеко не всегда по разным причинам. Во-первых, они нередко уничтожались посланниками вместе с другими документами, если возникало опасение, что государственно значимая информация может попасть в чужие руки. Так, Иван Хохлов, глава русского посольства в Бухарию в 1620-1622 гг., докладывал царю, что его люди зарыли в землю часть документов, а потом не смогли найти место «захоронки» [6. С. 444]. Во-вторых, публикацию сдерживает и объем столбцов: например, наказ, данный стольнику И.Д. Милославскому и дьяку Л. Лазоревскому при отправлении послами в Царьград в 1642 г., даже при утраченном конце документа, занимает более 100 страниц печатного текста [7. С. 1-102]. Поскольку собственно отчет дает достаточно полное представление о «вводной инструкции», то предпочтение при издании отдавалось первому.

Наказ обычно включал: 1) строгий маршрут поездки; 2) поручения посланникам, включая росписи подарков; 3) нормы поведения за границей, особенно этикет ведения переговоров; 4) содержание ответов на возможные вопросы принимающей стороны. При этом, в зависимости от обстоятельств поездки, он мог иметь и другой состав. Например, в наказных памятях XVII в. посольствам в Цинскую империю по вполне понятным причинам отсутствуют «маршрутные листы». Так, Ф.И. Байкову предписывалось «проведать подлинно» - путь «сухой», «водяной» или горами, «и сколько от которого города до которого города или от улуса до улуса верст, или милей, или днищ, и на чом сухим путем ходят - на лошадях ли или на велбудах, и сколько от которого города за провоз найму со вьюка дают, и в которой китайской украинной город из улусов или ис каких мест ни буди приезжают, и Китайскою землею от украинного города до стольного города Канбулука сколько недель или дней переезжают, и сколько в Китайском государстве от которого города и места до которого города ж места дорогою верст, или миль, или днищ считают... и которою дорогою ближе и безстрашно» [5. С. 162]. В свою очередь, в наказе Н.Г. Спафарию, получившему перед поездкой росписи пути Ф. Байкова и С. Аблина, указано «от Тобольска по дороге до пору- 
бежного китайского города изобразити все землицы, городы и путь на чертеже» [5. С. 345].

Правила предписывали очередность речей участников миссии, характер их исполнения (сидя, стоя), «одаривание» и «отдаривание» иноземцев в соответствии со статусом последних и т. д. От приказных дьяков требовалось предугадать вопросы принимающих посольство и дать нужные варианты ответов на них, которые бы соответствовали государственной политике и не могли сорвать ход дипломатических переговоров. Обычно возможные вопросы начинались с фразы «а будет (имярек) учнет говорить (спрашивать / nыттать)» / «взмолит»)...», ответы - с «а молвить на то...», «речь говорить / сказать / мольтьь напротив сего...». Образец общего резюме: «О тех делех держать ответ, смотря по их речам, учтиво и осторожливо, чтоб великого государя имени было к чести и к повышению, и лишних речей не говорить и собою ничего не всчинать» [8. С. 526]. Так, Ф.И. Байкову наказом запрещалось тесное общение с приказными и «ближними» людьми правителя Китая до встречи с последним [5. С. 153], кланяться «в порог», целовать богдыхана в ногу [5. С. 154-155], «застольничать» с царем при участии в нем послов других стран [5. С. 159]. В случае соблюдения условий двусторонней встречи посланнику приказывалось «за столом сидеть учтиво и остерегательно, $u$ не упиватца, и непристойных слов не говорити. А о чем с ним цуарь или ближние ево люди за столом учнут говорить, и ему ответ давать, выслушивая их речей остерегательно, чтоб государскому имени было кчести и к повышенью, а Московскому государству ко всякому добру» [5. С. 159].

В соответствии с наказом посольский отчет представлял дневник путешествия в чужую страну, но писанный не для себя, а «для деловых целей, для нужд производства Посольского приказа в первую очередь» [1. С. 319]. Он включал описание пути, всего увиденного во время поездки, встреч, содержания бесед с иноземцами. Например, в статейном списке Г.И. Микулина (посольство в Англию 1601 г.) читаем:

И сентября в 8 день учало быти на море погодье великое встречное. И носило корабли сем ден, и шли с великим страхованьем, спустя парусы с великою нужею.

И сентября в 14 день, в неделю, пришли Аглинские земли к берегу против аглинского городка Албрехта. И пошли карабли блиско берега по левой стороне <...> а те все городки, которых или мимо, камены, с посады; и села стоят по берегу - вотчины княжетикие, и боярские, и алдраманов, и гостей.

$<\ldots>$ И того ж дни Григорей и Ивашко ис карабля высели под городком под Гравзендем; и встретили Григорья и Ивашка того городка приказной человек, а с ним посадиких людей человек з двести; а встретил у судов. А в те поры з городка из караблей стреляли ис пушек; а провожали Григорья и Ивашка приказной человек и гость Иван Ульянов и посадияие люди до подворья и поставили на гостине дворе; а гость Иван Ульянов, поставя на подворье и устроя, поехал тотчас в Лунду. А для корму и береженья оставил у Григорья англичан же торговых людей: Семена Яковлева да Томаса Ондреева, которые ехали с Ываном с Москвы [9. С. 158-159].

Важной задачей посланников был также сбор разного рода сведений о чужеземной стране и сопредельных государствах. Так, в наказе Иоанна Ва- 
сильевича 1493 г. посланникам к мазовецкому князю Конраду сказано: «Да смотрити Асанчюку и Третьяку того и пытати им, кого будет пригоже, чем был послушен тот князь королю Казимеру, служил ли ему, давал ли ему подать какову, и кому он ровен иным князем, и что его княженье, и велика ли его земля, и сколь силен, люден ли или нелюден, и сколко городов, и послушнь ли ему люди, и мочно ли ему от Казимеровых детей от королевых отстати и противу его стояти, и те городы мощно ли ему назад взяти, которые у него король взял, и колко тех городов, и как им имена, и к которой земле, к Полской ли или Литовской? А брат его на уделе ли жсивет или с ним в одном месте, мирен ли ему или немирен, каково его дело с братом и которые городы за братом и которые за ним? А с прусьским магистром в одиначстве или не в одиначстве, и что его дело с магистром прусским? Всего того смотрити и пытати, кого будет пригоже [6. С. 379-380]. Предписываемая тактика сбора информации вполне соответствовала духу времени: Проведыввати всякими мерами накрепко тайным делом, припоя и прикормя к себе пристава или иных тамошних людей, чтоб ему гораздо был хто верен и в ком почает правды, и подаря чем пригоже [5. С. 160].

Ответы на подобные вопросы оформлялись потом в виде так называемых вестей (вестовых списков). Например: А вестей Иван Хохлов сказал. Сльшиал он, будучи в Бухарех и в Юргенче <... Бухарская де ныне земля на двое. На государстве 2 брата родных: столной Бухара город и иные города за болшим за Мамкулием циарем, а другая половина за братом его за Недир-ханом, город Балх с городы <..>. А городов де в Бухарской земле сказывают с 30. А как их зовут, имян сказати не помнит [6. С. 420, 423]. На местах и в московских приказах на основе разновременных документов создавались сводные тексты с описанием той или иной страны. Так, «снисканием» стольника и тобольского воеводы П.И. Годунова в 1669 г. была создана своего рода рукописная энциклопедия, содержащая многообразные сведения о юго-восточных соседях России, - «Ведомость о Китайской земле и о глубокой Индеи». [10. С. 212-219]. С.О. Долгов, публикатор одного из списков памятника, очень высоко отозвался о данном тексте: «Слог точный и типичный, чисто народный слог, ставит эту «Ведомость» неизмеримо выше всех искусственных «извитий и сплетений словес», которыми гордились наши книжники XVI и XVII века...» (цит. по: [10. С. 209]). Иллюстрацией к сказанному могут служить следующие отрывки, где передан миф о Далай-ламе, рассказывается о климате Китая и вере жителей Индии:

А как месяи млад, так и он Далай млад.

А как месяи в вперекрое, и он в то время всередович.

А как месяц в полне, и он в то время стар: он же умирает, и опять он же родития.

A иные про то говорят, что ложь [10. С. 218].

A зимы у них всего три месяиа, а летом у них живут жары, а меж тепльх дней живут и холоды, а по вечерам и всегды гораздно холодно бывает [C. 216].

А вера их: молятиа болваном и веруют в корову [С. 219].

Отдельным документом, помимо вестей, могло оформляться также описание дороги, которое называли дорожник, путник или роспись дороге (ny- 
$m u)$. На их основе создавались сводные географические справочники с указанием возможных маршрутов из одной точки в другую и расстояний между ними. Например:

Роспись, куды путь конной от Яицкаго города х Китайскому ичарству.

От Яицкаго же города до бухарского же города Самархани конной езды пол-2 недели. От Самархани до бухарского города Водокшани 1 неделя. Тут камень лал добывает. А от Водокшани до Китайскаго царства скорою ездою 3 месяиа.

И всего от Яииякаго города до Китайскаго ияарства езду 15 недель, а вьюками будет вдвое. А и ближе того есть иной путь к тому же Китайскому царству степью, и тем путем проехать невозможно, потому что в тех степях кочуют калмыки и татаровя и инье многие кочевные люди [11. C. 230]. Включение в тексты дорожников описаний достопримечательностей мест породило прообраз современных путеводителей, что соответствует античному жанру литературы путешествий под названием итинерарий (инитерарий, интерарий) - от лат. itinerari - 'путешествовать'.

Как показывает материал, статейные списки позднего типа представляют собой порой механическое соединение подневных записей событий с текстами получаемых и отправляемых послами документов, что превратило их в сборники документов - архивы посольств. Так, чистовой вариант статейного списка Ф.А. Головина в Китай и Маньчжурию 1689 г. написан на 1256 лис$\operatorname{tax}^{1}$. Это слово даже входит в название некоторых из них: например, отчет А.А. Матвеева о неофициальной поездке в Париж озаглавлен уже по-новому: «Архив, или Статейный список, Московскаго посольства, бывшаго во Франции из Голандии инкогнито в прошлом, 1705 г., сентября в 5 день» [12]. «Неравномерность» развития данного жанра подчеркивал Д.С. Лихачев, указав на тяготение одних отчетов к литературной художественности, а других - к «деловитости» служебных документов [1. С. 322-323].

Итак, посольские отчеты дошли до нас в виде статейных списков, выделенных из их состава дорожников, вестовых списков (вестей), на основе которых создавались сводные росписи и ведомости. По сути, расспросные речи и сказки участников миссии представляют собой близкие по содержанию варианты текстов статейных списков, нередко отличающиеся лишь более разговорным языком. В доказательство тезиса предлагаем сравнить две редакции отчета, расспросные речи и сказку И. Петлина «со товарищи» 16191620 гг. [5. С. 79-95]. Информацию (самую общую) о поездке в «иноземье» содержат также отписки воевод и челобитные участников похода, в которых они обращаются с просьбой о прибавке жалованья за тяготы службы в «посылках». При разной степени подробности описания и степени официальности изложения событий все названные приказные жанры представляют ценнейший материал для многоаспектных исследований, но особый интерес из них вызывают статейные списки, поскольку остальные документы не имели строгой специализации для посольской деятельности.

Наиболее полное представление о посольских отчетах в фондах РГАДА (Москва) дано Н.М. Рогожиным и А.А. Богуславским [13]. Составленная ими

\footnotetext{
${ }^{1}$ РГАДА, ф. 62, д. 10.
} 
база данных ${ }^{1}$ включает описи дел по странам (фондам) с указанием дипломатических агентов. Справочная часть содержит высоко информативные разделы: «Публикация посольских книг», «История изучения», «Состав и содержание», «Реконструкция утраченных книг и первичного состава сохранившихся книг», «Библиография». Подобная работа по материалам других архивов, прежде всего местных, а особенно их издание, могли бы существенным образом продвинуть изучение этих памятников, интересных по ряду параметров. Идеальным вариантом видится создание единого электронного архива документов, в том числе рукописных, размещение которых в сети Интернет уже начато ${ }^{2}$.

Вполне ожидаемо эти источники привлекли первоначально внимание историков, специалистов по истории русской дипломатии, для которых отчеты послов по значимости и информативности стоят на первом месте среди архивных документов. Так, публикатор ряда статейных списков князь Г.Д. Хилков особо подчеркивал их роль: «Если бы мы имели напечатанными все подобные наказы, какие только покоятся в разных книгохранилищах России, то, бесспорно, мы знали бы нашу древнюю дипломатию нисколько не хуже нынешней» [6. С. 388]. О внимании историков к отчетам послов свидетельствует библиография в указанном обозрении [13], искусствоведов - работы С.В. Хачатурова [14], О.С. Евангуловой [15], литературоведов - исследования $[1 ; 16 ; 17 ; 18 ; 19$ и др.].

Обращение языковедов к этим памятникам связано во многом с зарождением и становлением лингвистического источниковедения, задачами которого стало «исследование источников со стороны их лингвистической ценности и информационности» [20. С. 10-11]. Призыв к вовлечению статейных списков в научную сферу лингвистов прозвучал в статье А.М. Сабениной, раскрывающей тематическую содержательность памятников. В частности, исследовательница считала, что «наиболее интересны по содержанию и манере изложения списки XVII в., точнее, его второй половины, когда окончательно сложились характерные особенности этого жанра» [21. С. 65].

Издание памятников по историческим правилам определило тематику лингвистических работ на данном материале, значительное число которых посвящено приказному стилю, выявлению основы русского литературного языка $[3 ; 22 ; 23 ; 24 ; 25]$. На специфику стилистики этих текстов, их переходный характер обращал внимание еще Д.С. Лихачев: «Литература и деловая письменность борются в этих посольских повестях, попеременно одолевая друг друга» [1. С. 346]. О.В. Никитин предлагает видеть в них своеобразное продолжение светской летописной традиции [3. С. 81-82]. Перед нами деловой текст с конкретно-информативным характером изложения событий, привязанных к рамкам определенного пространства и времени. При этом, как и в случае с хронографами, в восприятии, интерпретации событий, да и в целом всего виденного, незнакомого посланнику до момента поездки, неизбежно проявляются его индивидуальность, его ценностный мир, словарный запас,

\footnotetext{
${ }^{1}$ Cм.: http://www.orientalistica.ru/resour/psd/index.htm (версия 2007 г.).

${ }^{2}$ См., например, статейный список Василия Айтемирова о посольстве в Крым в 1692-1695 гг. из собрания библиотеки Троице-Сергиевой лавры (http://old.stsl.ru/manuscripts/ medium.php? col= 2 \& manuscript=019).
} 
умения и навыки строить связный рассказ. Характеризуя данный жанр деловой словесности, О.В. Никитин отмечает ряд его структурно-типологических и языковых особенностей, в числе которых: документальность, подлинность, утилитарность, тематическая специфика, отражение в диалогах культурноречевого поведения участников переговоров, разностилевой характер текста, выражающийся в сочетании элементов официально-делового (приказного) и народно-разговорного типов языка. Выявленные черты позволили исследователю указать на «лингвистическое перепутье» жанра, «гибкость» и «лояльность» по отношению к трафаретам [3. С. 88]. Он же отмечал, что дипломатический язык формировался в условиях сплава церковно-книжного, официально-делового и народно-разговорных (в том числе фольклорных) элементов, утверждая, что «изучение статейных списков имеет существенное значение и для выяснения проблемы взаимодействия устной и письменной речи и характера их отражения в деловых текстах» [3. С. 89]. Складывающийся в пределах жанра дипломатический вариант «подьяческого наречия» может быть проиллюстрирован следующими отрывками из посольского отчета: « $A$ как учели отпевати обедню, и королевна, подшед кместу, где попы служат, приклякнула на колени» [9. С. 176]; «...а как у королевны стол шел, и перед нею играли во многие игры многие игрещьы» [9. С. 177]; «...воевать хаживал в великих воеводах и везде ославился великим богатырством» [9. С.179]; «...не покручинитись подождати от королевны на твои речи приказу» [9. С. 200].

Кроме стилистических, на материале посольских отчетов выполнены работы грамматической [26] и лексической проблематики. Последняя представлена общей характеристикой номинативного состава одного из списков [27], описанием отдельных тематических объединений лексики - дипломатической [28; 29], названий экипажей [30]. Памятники также предоставляют богатый материал для исследования лексики природного мира, градостроения, военного дела, бытовой, административной и др. Они же важный источник для изучения новой для разных периодов лексики, главным образом заимствованной. Как показывают материалы Сл. РЯ XI-XVII вв. [4], они явились источником для таких слов, как АЗНАУРЬ (дворянин (у имеретинов); т. 1, с. 24), АЙВА (т. 1, с. 25), КАБАКЪ ${ }^{2}$ (селение; т. 7, с. 7), КОМЕНДАНТЬ (т. 7, с. 262), КОРФЕТИ (сладости; т. 7, с. 347), МАЙДАНЪ c. 9), САРАЙ 1 (дворец; т. 23, с. 63) и многих других. Именно статейные списки отражают робкие шаги вхождения ксенолексики в русский язык: «Видели в Ливорне птицу, называют струи, велика, ноги что у коровы, а ест железо, и камень, и кости, в вышину человека с полтора а перье на ней морховато, серо, что носят немцы на шляпах» [17. С. 273] - страус; «и Виницея стоит на той же морской губе, кругом ея и по всем улищам вода, ездят в мелких судах, по их называют гундульл»-гондоль [17. С. 277].

Лингвистическую содержательность посольских отчетов существенно повышает тот факт, что они дошли до нас, во-первых, в сходных текстах разных жанров, во-вторых, в ряде редакций одного жанра. Так, первое обстоятельство позволяет обоснованно выявлять жанрообразующие признаки документов, второе - изучать прагматику текстов в плане языкового выражения авторских интенций, поскольку варианты отчетов создавались разновременно, в различных условиях - условиях дороги или же по возвращении домой 
или в Москву, что неизбежно вносило корректировку в версии видения и изложения событий поездки. Например, любопытным представляется сравнение чернового и белового вариантов статейных списков ${ }^{1}$, или, как в случае Ф.И. Байкова, первичного (тобольского) и окончательного (московского).

Перед его миссией в Китай (1654-1658 г.) были поставлены две задачи. Первая - установление добрососедских отношений («Каков ко государю бугдыхан-ияарь - любителен ли и рад ли тому, что государь прислал к ним с ним, Федором, к нему, бугдыхану-иарю, свою государеву грамоту? <..> Будет вперед у ияарского величества с китайским бугдыханом-ияарем дружба и любовь и ссылка будет?» [5. С. 160, 162]). Вторая - налаживание торговых связей («Да Федору ж, будучи в Китаех, проведать достаточно: какие в Китайском государстве узорочные товары и каменье бывает, и тут ли те товары делают, а каменье добывают или отколе привозят, и бархаты, $u$ отласы, и гладкие камки, и тафты в Китаех делают ли или привозят, и сколь дорого купят <..> и каким путем, сухим или морским, ис которых государств те товары привозят, и сколь близки или далеки те государства, ис которых те узорочные товары привозят, и какие товары прибыльнее в Московское государство у них покупать, а из московского государства к ним в Китайское государство посылать...» - с. 161). Обе они не были выполнены, так как «пред очи» царя посол допущен не был, привезенные русские товары распроданы были не полностью. Причиной тому послужила сложная политическая ситуация в Китае, вызванная завоеванием его маньчжурами и сменой императорской династии в стране.

Желая произвести благоприятное впечатление об исполнении возложенных на посольство обязанностей, в более раннем, сибирском, списке писец подчеркивает невозможность нормального хода переговоров, что заставило посла проявить инициативу, несовместимую со статьями полученного наказа. Так, Ф.И. Байков добровольно «государевы поминки по росписи отдал приказным людем марта в 4 день» (с. 177), хотя вручить должен был их только лично. Будучи выпровожен из столицы («И выслали не само его вежливо, $и$ царьскому величеству чести никакой не учинили»- с. 178), с дороги предпринял отчаянную попытку добиться положительного результата своей поездки, послав гонца ко двору с обещанием: «...во всем де цุаря вашего повеление стану править - в приказ де я к приказным царевым людем поеду, и государеву любительную грамоту приказным ијаревым людем подам, и кланятися по вашей вере, припадши на колено в шапке, стану, и как де годно царю вашему, во всем повеления его слушать стану» (с. 160-161). Смысл сообщения о вопиющих нарушениях норм ведения переговоров с равными по положению дворами можно усмотреть такой: посол готов жертвовать карьерой и собственной головой ради достижения поставленной государем задачи. В московской редакции отчета избрана другая тактика - Ф.И. Байков следовал во всем букве наказа: «многажды» (не дважды, как в тобольском списке) отказал «чиновным людям» в визите в приказ («...не быв де мне у вашего изаря, в приказ ехать непригоже» (с. 186), не испугался угроз: «И они ему гово-

\footnotetext{
[17].

${ }^{1}$ См., например, археографический обзор статейного списка Г.И. Микулина в [9. С. 348-349] или
} 
рили: царь де тебя велит казнить, что де ты ияарева указу не слушаешь. И посол им говорил: хотя де изарь велит по составом меня рознять, а ијаря вашего очей не видев, к вам, приказным людем, в приказ не еду и государевь любительные грамоты вам не отдам» (с. 187). По этой версии, поминки у него «взяли сильно», из Канбалыка (Пекина) не выслали, а отпустили (с. 190), о попытке связаться на обратном пути с маньчжурским двором не упоминается совсем.

Наличие не одного варианта изложения событий позволяет говорить о проявлении индивидуального, личностного, начала в делопроизводственном стандарте, так как запись рассказа о путешествии участников посольства (нередко - только его главы) осуществляли разные люди - носители разных говоров, разной степени выучки. В частности, этот подход дает материал для исследования номинативного варьирования на всех языковых уровнях. Ср. редакции упомянутого выше статейного списка Ф.И. Байкова [5]: «А как одолели мунгальцы Китайским иарством, и тогда тот Даба-иарь обесился» (с. 179) - «А как одолели мугальиь Китайским изарством, и тому де лет с 13, и тогда де тот Дайба-хан удавился» (с. 189). «А волосы на главах по-немецки» (с. 179) - «А волосы на головах с немеикого переводу» (с. 189). «А платья иветнаго мужеск пол и женск не носят, носят платье все черное» (с. 179) «А платье носят мужеск пол и женеск смирное, а цвветного платья кроме царева двора и уванов не носят» (с. 189).

Реальные ситуации, с которыми приходилось сталкиваться участникам посольств, были многообразнее предусмотренных наказом случаев, а официальные установки (так надо) не могли не корректироваться координатами внутреннего ценностного мира посланника. Как указывает О.В. Никитин, «на первый план здесь выходит языковая личность как носитель приказной культуры и создатель делового произведения. От ее эстетического (в том числе и «делового») вкуса во многом зависели стилистический орнамент посольской переписки и характер отображения в ней индивидуальных речевых особенностей» [3. С. 88]. Интересно, что в научной литературе XIX в. можно встретить диаметрально противоположные оценки первых посланников России, авторов отчетов. Так, В.О. Ключевский писал: «Неподготовленные и равнодушные, с широко раскрытыми глазами и ртами, смотрели они на нравы, порядки и обстановку европейского общежития, не различая див культуры от фокусов и пустяков, не отлагая в своем уме от непривычных впечатлений никаких помыслов» [31. С. 236]. Н.Н. Оглоблин же, обозреватель и исследователь сибирских памятников делового письма, с восторгом отзывается о «непатентованных дипломатах». Он представляет читателям три статейных списка по итогам посольств к калмыкам и «мугалам» сибирских служилых людей, награждая каждого из них характеристикой, очевидно выявляющейся из текстов: Меньшой Ремезов - «тип наивного дипломата» [2. С. 157], толмач Панфил Семенов, возглавивший посольство после смерти сына боярского Ерофея Заболоцкого, - «ретивый Панфил», Москвитин - «очень тонкий наблюдатель» [2. С. 160].

Да, наказ регламентировал, что́ следовало отразить в отчете, но автор сам выбирал степень детализации описания и описывал так, как умел, как ему подсказывали опыт и воображение. Яркое индивидуальное начало делает 
этот источник информативным для его изучения в русле лингвоперсонологии, которое лишь намечено современными исследованиями. К первым опытам анализа посольских документов в этом аспекте следует отнести статьи Л.С. Андреевой о П.А. Толстом как об элитарной языковой личности [32] и О.А. Слугиной, в основу которого легли три разновременных отчета о поездке в Китай: томского казака И. Петлина (1618-1619), сына боярского Ф.И. Байкова (1654-1658), опытного дипломата Н.Г. Спафария (1675-1676) [33]. На материале выявленных номинативных сфер преимущественного описания исследовательницей доказано, что создатели отчетов смотрели на чужой мир глазами тех, кем они являлись: служилым человеком, администратором и торговцем, политиком. В развитие темы следует заметить, что личностное начало текстов, несомненно, также обнаруживается в способах и средствах номинации инокультурной действительности. «Наивно-прагматический способ осознания мира», соответствующий данному периоду в истории русской эстетической мысли [18. С. 6], проявляется в этих текстах во всей полноте:

«Да в садах же деревье великое, а на них овощь, что яблоко, величиною з голову человеческую, а человеку ево съесть одному невозможно; а находит на яблоко, а сладко таково, подобно меду, а отзыв огурешной, а семя яблошное, а цуветом посветлее лимону, и тот овощь китайцыь любят всех овощей, а называют его нашпады» [10. С. 215]. Или: «Сделаны два яблока превеликих добре, а на тех яблоках написаны государства все, и планиды, и беги небесные; а те яблоки переворачиваются на все стороныл [17. С. 274]. Статейные списки развивали русское общество, знакомя с иноземными культурами, приучая к мысли, что чужое заслуживает изучения и уважения: «А люди ласковы и советны, и в домех у них нескрытно, и входы в домы их свободно» [10. С. 213]; «А на улицах копаны колодези, а по обе стороны улии копаны борозды великие, приведены в речки и в озера, когда бывает дождевая вода, и теми бороздами та дождевая вода из улии и переулков збегает, и грязей в улицах не бывает, и из дворов на улииь вывожены трубы для дождевой же во$\partial b l \gg[$ [5. С. 188].

При общей приказной схеме, обеспечивавшей посольским отчетам определенную трафаретность, стандартизованность, они сохраняют индивидуальное лицо, что объясняется как внешними объективными факторами (особыми условиями, специфическими задачами посольств, не менее важно - отсутствием строго заданных образцами норм ведения записей), так и субъективными манерами писцов, обусловленными разницей последних в происхождении и уровне образованности ${ }^{1}$. На общее целеполагание делопроизводственных жанров, организующее текст структурно и содержательно, налагаются авторские интенции, ограниченные в реализации личностными потенциями создателей отчетов.

Об авторитете жанра свидетельствуют так называемые подложные статейные списки, созданные на основе вымышленных поездок [34. С. 218-254]. Этот же факт указывает направление развития посольских отчетов - в путе-

\footnotetext{
${ }^{1}$ В полной мере это замечание следует относить и к жанру наказа (наказной памяти) посольству, также заслуживающему внимания лингвистов.
} 
вую литературу, сначала в виде личных дневников неофициальных лиц ${ }^{1}$, отчетов о путешествиях членов царской семьи, научных описаний - прежде всего различных российских регионов («журнал путешествию / путешествия/ путешествий / о путешествии», «записки (описание/начертание) путешествия / поденные / дневные / журнальные / путевые / о поездке / о плавании» и др. ${ }^{2}$ ), затем - собственно художественных текстов в жанре «путешествия», иначе - травелога. Д.С. Лихачев, говоря о роли статейных списков в развитии русской литературы, даже называет Посольский приказ «своеобразным литературным центром XVII в.» [1. С. 321].

Все сказанное свидетельствует о том, что посольские отчеты являются ценным лингвистическим материалом и их изучение имеет большие перспективы, обоснованные богатством и разнообразием отраженных в источниках данных о языке и его носителях одного из интереснейших периодов русской истории. Причем степень прямой или косвенной отраженности в них лингвистической информации может быть существенно повышена при обращении исследователей к оригинальным архивным рукописям, а в случае их публикации по лингвистическим правилам обязательно появятся и новые аспекты описания языковых фактов как отклик на расширение круга исследователей этих источников.

\section{Лuтература}

1. Лихачев Д.С. Повести русских послов как памятники литературы // Путешествия русских послов XVI-XVII вв.: Статейные списки. М.; Л., 1954. С. 319-346.

2. Оглоблин Н. Сибирские дипломаты XVII века (Посольские «статейные списки») // Ист. вестн. (историко-лит. журн.). 1891. № 10. С. 156-171.

3. Никитин О.В. Деловой язык русской дипломатии XVI-XVII вв. (формальные и стилеобразующие средства) // Науч. докл. высш. шк. Филол. науки. 2005. №1. С. 8-89.

4. Словарь русского языка XI-XVII вв. М.: Наука, 1975-2008. T. 1-28.

5. Русско-китайские отношения в XVII в.: Материалы и документы / под ред. В.С. Мясникова. М.: Наука, 1969. Т. 1: 1608-1683. 612 с.

6. Сборник документов по истории России 1493-1743 // Сборник князя Хилкова. СПб., 1879. $629 \mathrm{c}$.

7. Наказ, данный стольнику Илье Даниловичу Милославскому и дьяку Леонтью Лазоревскому при отправлении послами в Царьград // Временник императорского Московского общества истории и древностей российских. М., 1851. Кн. 9, отд. 2. С. 1-102.

8. Наказ от царя Феодора Алексеевича подьячему Алексееву, посланному гонцом с грамотою к польскому королю в 1680 г. // Московский телеграф. 1830. Ч. 36, № 24. С. 522-527.

9. Путешествия русских послов XVI-XVII вв.: статейные списки / ред. Д.С. Лихачев. М.; Л.: Изд-во АН СССР. 1954. 490 с.

10. Скачков П.Е. Ведомость о Китайской земле // Страны и народы Востока: География, этнография, история. М., 1961. С. 206-219.

11. Русские географические справочники XVII в. (из сборника в Собрании Московской духовной академии) // Записки отдела рукописей ГБЛ. Вып. 21. М., 1959. С. 220-240.

12. Шаркова И.С., Люблинская А.Д. Архив, или статейный список: А.А. Матвеев и его труд. URL: // http://oldvostlit.info/Texts/rus12/Matveev/pred.htm (дата обращения: 30.11.2014).

\footnotetext{
1 «Эти дневники путешествий своею обстоятельностью, точностью и наблюдательностью во многом обязаны литературной традиции статейных списков. Отсюда они заимствуют умение вести повествование, стремление запечатлеть все новое, свой патриотизм, порой критическое отношение к иноземным обычаям» [1. С. 337-338].

${ }^{2}$ Обзор литературы этого жанра см. в работах [21. С. 130-150; 18].
} 
13. Рогожин Н.M., Богуславский А.А. Посольские книги России конца XV - начала XVIII в. URL: http://www.orientalistica.ru/resour/psd/index.htm (версия 2007 г.).

14. Хачатуров С.В. Готическое архитектурное наследие в путевых записках петровского времени (доклад, прочитанный на Федоро-Давыдовских чтениях в 1999 г.). URL: http://www. archi.ru/ files/publications/virtual/hachaturov.htm (дата обращения: 20.11.2013).

15. Евангулова О.С. Изобразительное искусство в России первой четверти XVIII века: Проблемы становления художественных принципов Нового времени. М.: Изд-во МГУ, 1987. $294 \mathrm{c}$.

16. Лихачев Д.С. Зарождение и развитие жанров древнерусской литературы // Исследования по древнерусской литературе. Л., 1986. С. 79-95.

17. Казакова Н.А. Статейные списки русских послов в Италию как памятники литературы путешествий (середина XVII в.) // ТОДРЛ. Т. 41. Л., 1988. С. 268-288.

18. Травников С.Н. Писатели петровского времени: литературно-эстетические взгляды (путевые записки): учеб. пособие. М.: МГПИ им. В.И. Ленина, 1989. 104 с.

19. Николаенко O.H. К вопросу о становлении жанра травелога в литературе XVI-XVII вв.: Субъективное начало в «Статейных списках» Д. Лихачева // Вестн. Том. гос. ун-та. 2014. № 379. C. 24-27.

20. Котков С.И. О предмете лингвистического источниковедения // Источниковедение и история русского языка. М., 1964. С. 3-13.

21. Сабенина А.М. Статейные списки и их значение для истории русского языка // Русский язык и источники для его изучения. М., 1971. С. 59-85.

22. Мальцева И.М. Записки путешествий XVIII века как источник литературного языка и языка художественной литературы (к постановке вопроса) // Язык русских писателей XVIII века. Л., 1981. С. 130-150.

23. Никитин О.В. Деловой язык и литературные тексты XV-XVIII вв.: М.: Изд-во Моск. гос. обл. ун-та, 2004. $324 \mathrm{c}$.

24. Шадрина М.Г. Эволюция языка «путешествий»: автореф. дис. ... д-ра филол. наук. М., 2003. $65 \mathrm{c}$.

25. Юрицына И.А. Статейные списки в системе письменности русского литературного языка конца XVI начала XVII вв. (историко-лингвистический аспект): автореф. дис. ... канд. филол. наук. Алматы, 2000. 22 c.

26. Андреева Л.С. Формы имен существительных в дипломатической корреспонденции Московской Руси (на материале статейных списков XVI-XVIII вв.): автореф. дис. ... канд. филол. наук. Казань, 1969. 24 с.

27. Валькова Д.П. Лексика «Путешествия» П.А. Толстого: (К истории формирования словарного состава русского национального языка): автореф. дис. ... канд. филол. наук. Л., 1965. $20 \mathrm{c}$.

28. Сергеев Ф.П. Русская дипломатическая терминология XI-XVII вв. Кишинев: Картя Молдовеняскэ, $1971.219 \mathrm{c}$.

29. Сабенина А.M. Лексика сферы дипломатических отношений в русском языке XVII в. (по материалам статейных списков русских послов): автореф. дис. ... канд. филол. наук. М., 1971. $16 \mathrm{c}$.

30. Царапкина Л.В. Обозначения английских экипажей в статейных списках русских послов // Журнал научных публикаций аспирантов и докторантов. URL: http://www.jurnal.org/ articles/2008/ fill26.html (дата обращения: 30.04.2014). $422 \mathrm{c}$.

31. Ключевский В.О. Сочинения: в 8 т. Т. 4: Курс русской истории. М.: Соцэкгиз, 1958.

32. Андреева Л.С. Элитарная языковая личность российской дипломатии начала XVIII века: Петр Андреевич Толстой // Л.Н.Толстой - это целый мир: Материалы XXXI Междунар. Толстовских чтений, посвященных 180-летию со дня рождения Л.Н. Толстого: 2 ч. Тула, 2008. Ч. 2. C. $27-35$.

33. Слугина O.A. Номинативные сферы в обозначении неизвестного как проявление личностного начала (на материале статейных списков XVII в.) // Вестн. Новосиб. гос. ун-та. Сер.: История, филология. 2011. Т. 10, вып. 9: Филология. С. 40-44.

34. Каган М.Д. «Повесть о двух посольствах» - легендарно-политическое произведение начала XVII века // ТОДРЛ. М.; Л.,1955. Т. 11. С. 218-254. 


\section{EMISSARIES' ACCOUNTS OF THE 17TH CENTURY: VARIETY OF GENRES, LINGUIS- TIC RICHNESS OF CONTENT.}

Tomsk State University Journal of Philology, 2015, 1(33), pp. 51-65. DOI 10.17223/19986645/33/5

Starikova Galina N., Tomsk State University (Tomsk, Russian Federation). E-mail: gstarikova@ yandex.ru

Keywords: study of linguistic sources, emissaries' accounts, "prikaz" language, linguistic richness of content, Russian language history.

The 17th century in Russian history is the period of geographical discoveries, territorial expansion and foreign diplomatic contacts development. Active state business life caused the appearance of "prikaz" language, within which the special diplomatic sort of language was formed from the mixing of church-literary, documentary and popular speech elements. This type of language is presented in numerous emissaries' accounts about their travels to different countries. In these texts, the commonplace standardization is organically combined with individual features. The emissaries' reports continued the secular tradition of chronicles and greatly influenced the genre repertoire, the general development of secular literature in Russia, that is why they are an attractive material for research.

At first, historians paid attention to these materials, then specialists in the study of literature and art. Linguists recognized them as the information origin for the study of the documentary style, Russian literary language basis and diplomatic vocabulary history. These materials allow to extend this list of linguistic problems essentially, as there are two facts that seriously raise the linguistic richness of the content of emissaries' accounts. First, the reports are similar texts of different genres; secondly, there are some versions of one genre. Thus, the first fact allows to reveal the genre features of the documents validly, the second one to study the nominative variations and the linguistic expression of the author's intentions, as variants of reports were created in different time and in different circumstances: during the travel or after returning home or to Moscow, there inevitably were corrections of the trip event account.

The author thinks that the study of the origin from the linguopersonology point is the most interesting one, as emissary's individuality, his world-view, vocabulary, his skills and habits to make a connected narration become apparent through his perception of the strange world events which were unfamiliar to him before the trip. The naive-pragmatic way of world apprehension, characteristic of that period of Russian aesthetic thought history, is fully displayed in these texts. All the above-stated allows to affirm that the emissaries' accounts are the valuable linguistic material and their study has great perspectives based on the richness and diversity of the linguistic data and facts about their bearers during the most interesting period of Russian history.

\section{References}

1. Likhachev D.S. Povesti russkikh poslov kak pamyatniki literatury [Tale of Russian ambassadors as monuments of literature]. In: Likhachev D.S. (ed.) Puteshestviya russkikh poslov XVIXVII vv.: Stateynye spiski [Travels of Russian ambassadors in the 16th - 17th centuries: Reports]. Moscow - Leningrad: Izd-vo AN SSSR Publ., 1954, pp. 319-346.

2. Ogloblin N. Sibirskie diplomaty XVII veka (Posol'skie "stateynye spiski") [Siberian diplomats of the 17th century (Emissaries' reports)]. Istoricheskiy vestnik, 1891, no. 10, pp. 156-171.

3. Nikitin O.V. Delovoy yazyk russkoy diplomatii XVI - XVII vv. (formal'nye i stileobrazuyushchie sredstva) [Business language of Russian diplomacy in the 16th -17 th centuries. (formal and stylistic devices)]. NDVSh. Filologicheskie nauki, 2005, no. 1, pp. 8-89.

4. Slovar' russkogo yazyka XI - XVII vv., tt. 1-28 [Russian dictionary of the 11th -17 th centuries. Vols. 1-28]. Moscow: Nauka Publ., 1975-2008.

5. Myasnikov V.S. (ed.) Russko-kitayskie otnosheniya v XVII v.: Materialy i dokumenty [RussianChinese relations in the 17th century: Materials and documents]. Moscow: Nauka Publ., 1969. Vol. 1, $612 \mathrm{p}$.

6. Sbornik knyazya Khilkova [Collection of Prince Khilkov]. St. Petersburg: Tipografiya brat'ev Panteleevykh Publ., 1879. 629 p.

7. Nakaz, dannyy stol'niku Il'e Danilovichu Miloslavskomu i d'yaku Leont'yu Lazorevskomu pri otpravlenii poslami v Tsar'grad [Instruction given to stolnik Ilya Danilovich Miloslavsky and Deacon Leontiy Lazorevskiy when sending them as ambassadors to Constantinople]. In: Vremennik imperatorskogo Moskovskogo obshchestva istorii i drevnostey rossiyskikh [Annals of the Imperial 
Moscow Society of Russian History and Antiquities]. Moscow: Universitetskaya tipografiya Publ., 1851. Book 9, pt. II, pp. 1-102.

8. Nakaz ot tsarya Feodora Alekseevicha pod'yachemu Alekseevu, poslannomu gontsom s gramotoyu k pol'skomu korolyu v 1680 g. [Injunction of Tsar Feodor Alekseevich to Alekseev, a scribe, sent as a messenger with a letter to the Polish king in 1680]. Moskovskiy telegraf, 1830, pt. XXXVI, no. 24, pp. 522-527.

9. Likhachev D.S. (ed.) Puteshestviya russkikh poslov XVI-XVII vv.: Stateynye spiski [Travels of Russian ambassadors in the 16th - 17th centuries: Reports]. Moscow - Leningrad: Izd-vo AN SSSR Publ., 1954. 490 p.

10. Skachkov P.E. Vedomost' o Kitayskoy zemle [Statement on Chinese land]. In: Strany i narody Vostoka: Geografiya, etnografiya, istoriya [Countries and peoples of the East: geography, ethnography, history]. Moscow: Nauka Publ., 1961, pp. 206-219.

11. Russkie geograficheskie spravochniki XVII v. (iz sbornika v Sobranii Moskovskoy dukhovnoy akademii) [Russian geographical reference books of the 17th century. (from the collection in the Collection of the Moscow Theological Academy)]. Zapiski otdela rukopisey GBL, 1959, issue 21 , pp. 220-240.

12. Sharkova I.S., Lyublinskaya A.D. Arkhiv, ili stateynyy spisok: A.A. Matveev $i$ ego trud [Archive or report: A.A. Matveev and his work]. Available from: http://oldvostlit.info/ Texts / rus12/ Matveev/pred.htm. (Accessed: 30th November 2014).

13. Rogozhin N.M., Boguslavskiy A.A. Posol'skie knigi Rossii kontsa XV-nachala XVIII vv. [Ambassadorial books of Russia in the late 15th - early 18th centuries]. Available from: http://www.orientalistica.ru/resour/psd/index.htm.

14. Khachaturov S.V. Goticheskoe arkhitekturnoe nasledie v putevykh zapiskakh petrovskogo vremeni [Gothic architectural heritage in the travel notes of Peter's time]. Available from: http://www.archi.ru/files/publications/virtual/hachaturov.htm. (Accessed: 20th November 2013).

15. Evangulova O.S. Izobrazitel'noe iskusstvo v Rossii pervoy chetverti XVIII veka: Problemy stanovleniya khudozhestvennykh printsipov Novogo vremeni [Fine art in Russia in the first quarter of the 18th century: Problems of formation of artistic principles of modern times]. Moscow: Moscow State University Publ., 1987. 294 p.

16. Likhachev D.S. Zarozhdenie $i$ razvitie zhanrov drevnerusskoy literatury [Origin and development of genres of Old Russian literature]. In: Tvorogov O.V. (ed.) Issledovaniya po drevnerusskoy literature [Research in ancient literature]. Leningrad: Nauka Publ., 1986, pp. 79-95.

17. Kazakova N.A. Stateynye spiski russkikh poslov v Italiyu kak pamyatniki literatury puteshestviy (seredina XVII v.) [Reports of Russian ambassadors to Italy as monuments of travel literature (mid-17th century)]. TODRL, 1988, vol. XLI, pp. 268-288.

18. Travnikov S.N. Pisateli petrovskogo vremeni: literaturno-esteticheskie vzglyady (putevye zapiski) [Writers of Peter's time: the literary and aesthetic views (travel notes)]. Moscow: MGPI im. V.I. Lenina Publ., 1989. 104 p.

19. Nikolaenko O.N. On formation of the travelogue as a literary genre in the 16th-17th centuries. D. Likhachev's subjective view of diplomatic reports. Vestnik Tomskogo gosudarstvennogo universiteta - Tomsk State University Journal, 2014, no. 379, pp. 24-27. (In Russian).

20. Kotkov S.I. O predmete lingvisticheskogo istochnikovedeniya [On the subject of linguistic source studies]. In: Istochnikovedenie i istoriya russkogo yazyka [Source stuides and the history of the Russian language]. Moscow: Nauka Publ., 1964, pp. 3-13.

21. Sabenina A.M. Stateynye spiski i ikh znachenie dlya istorii russkogo yazyka [Diplomatic reports and their significance for the history of the Russian language]. In: Russkiy yazyk $i$ istochniki dlya ego izucheniya [Russian and sources for its study]. Moscow: Nauka Publ., 1971, pp. 59-85.

22. Mal'tseva I.M. Zapiski puteshestviy XVIII veka kak istochnik literaturnogo yazyka i yazyka khudozhestvennoy literatury (k postanovke voprosa) [Notes of travels of the 18th century as a source of literary language and the language of literature (on the question)]. In: Yazyk russkikh pisateley XVIII veka [The language of Russian writers of the 18th century]. Leningrad: Nauka Publ., 1981, pp. 130150.

23. Nikitin O.V. Delovoy yazyk i literaturnye teksty XV-XVIII vv. [Business language and literary texts of the 15th-18th centuries]. Moscow: MGOU Publ., 2004. 324 p.

24. Shadrina M.G. Evolyutsiya yazyka "puteshestviy": Avtoref. dis. d-ra filol. nauk [Evolution of the language of "travels". Abstract of Philology Dr. Diss.]. Moscow, 2003. 65 p.

25. Yuritsyna I.A. Stateynye spiski $v$ sisteme pis'mennosti russkogo literaturnogo yazyka kontsa XVI nachala XVII vv. (istoriko-lingvisticheskiy aspekt). Avtoref. dis. kand. filol. nauk [Diplomatic 
reports in the writing system of the Russian literary language of the late 16th and early 17th centuries. (historical and linguistic aspect). Abstract of Philology Cand. Diss.]. Almaty, 2000. 22 p.

26. Andreeva L.S. Formy imen sushchestvitel'nykh $v$ diplomaticheskoy korrespondentsii Moskovskoy Rusi (na materiale stateynykh spiskov XVI-XVIII vv). Avtoref. dis. kand. filol. nauk [Forms of nouns in the diplomatic correspondence of Moscow Russia: diplomatic reports of the 16th18th centuries). Abstract of Philology Cand. Diss.]. Kazan, 1969. 24 p.

27. Val'kova D.P. Leksika "Puteshestviya" P.A. Tolstogo ( $K$ istorii formirovaniya slovarnogo sostava russkogo natsional'nogo yazyka). Avtoref. dis. kand. filol. nauk [Vocabulary of "Travel" by P.A. Tolstoy (On the history of the formation of the vocabulary of the Russian national language). Abstract of Philology Cand. Diss.]. Leningrad, 1965. 20 p.

28. Sergeev F.P. Russkaya diplomaticheskaya terminologiya XI - XVII vv. [Russian diplomatic terminology of the 11th-17th centuries] Kishinev: Kartya Moldovenyaske Publ., 1971. 219 p.

29. Sabenina A.M. Leksika sfery diplomaticheskikh otnosheniy v russkom yazyke XVII v. (po materialam stateynykh spiskov russkikh poslov). Avtoref. dis. kand. filol. nauk [Vocabulary of diplomatic relations in the 17th-century Russian language by diplomatic reports of Russian ambassadors. Abstract of Philology Cand. Diss.]. Moscow, 1971. 16 p.

30. Tsarapkina L.V. Oboznacheniya angliyskikh ekipazhey v stateynykh spiskakh russkikh poslov [Designations of British carriages in diplomatic reports of Russian ambassadors]. Zhurnal nauchnykh publikatsiy aspirantov i doktorantov. Available from: http://www.jurnal.org/articles/2008/ fill26.html. (Accessed: 30th April 2014).

31. Klyuchevskiy V.O. Sochineniya. V 8-mi t. [Works. In 8 vols.]. Moscow: Sotsekgiz Publ., 1958. Vol. 4, 422 p.

32. Andreeva L.S. [Elite language personality of Russian diplomacy of the early 18th century: Pyotr Andreyevich Tolstoy]. L.N.Tolstoy - eto tselyy mir: Materialy XXXI Mezhdunarodnykh Tolstovskikh chteniy, posvyashchennykh 180-letiyu so dnya rozhdeniya L.N.Tolstogo: V 2-kh ch. [Leo Tolstoy is a whole world: Proceedings of the XXXI International Tolstoy's readings devoted to the 180th anniversary of the birth of Leo Tolstoy: In 2 parts]. Tula: Tula State Pedagogical University n.a. L.N. Tolstoy Publ., 2008. Pt. II, pp. 27-35. (In Russian).

33. Slugina O.A. Nominative area in designation of unknown objects as a personality's manifestation (on the material of "stateiny spiski" of XVII century). Vestnik Novosibirskogo gosudarstvennogo universiteta. Seriya: Istoriya, filologiya, 2011, vol. 10, no. 9, pp. 40-44. (In Russian).

34. Kagan M.D. "Povest' o dvukh posol'stvakh" - legendarno-politicheskoe proizvedenie nachala XVII veka ["A tale of two embassies", the legendary political work of the beginning of the seventeenth century]. TODRL, 1955, vol. 11, pp. 218-254. 